\title{
Transmissivity of Aquifer by Capture Zone Method: An Application in the Sete Lagoas Karst Aquifer, MG, Brazil
}

\author{
PAULO GALVÃO ${ }^{1}$, TODD HALIHAN ${ }^{2}$ and RICARDO HIRATA ${ }^{3}$ \\ ${ }^{1}$ Federal University of Ouro Preto, Department of Geology/DEGEO, Morro do \\ Cruzeiro Campus, s/n, 35400-000 Ouro Preto, MG, Brazil \\ ${ }^{2}$ Oklahoma State University, School of Geology, 105 Noble Research Center, Stillwater, 74078, OK, USA \\ ${ }^{3}$ Groundwater Research Center (CEPAS/USP), Institute of Geosciences, University \\ of São Paulo, Rua do Lago, 562, 05508-080 São Paulo, SP, Brazil
}

Manuscript received on July 1, 2016; accepted for publication on September 8, 2016

\begin{abstract}
Transmissivity is an important hydraulic parameter to determine the amount of water passed horizontally across a given saturated thickness of an aquifer. The techniques to quantify this parameter, such as grain size analyses or pumping tests, can have limitations of time/spatial scale, viability, or economically. One technique that can be used, but little adopted, is the capture zone analysis. In this paper, capture zone analytical equations were used to estimate transmissivity values in order to verify the effectiveness of this methodology as alternative in situations where other traditional methods present implementation difficulties. The results were compared with field data estimated by aquifer tests conducted in the same region. A sensitivity analysis was also performed to identify possible discrepancies between the analytical and field data results. The aquifer studied was the Sete Lagoas Karst Aquifer in the urban region of the municipality of Sete Lagoas, Brazil. The method proved to be a viable and economical tool, where the analytical values compared to the aquifer tests showed similarities, being confirmed by a sensitivity analysis. However, a reliable potentiometric surface map, which enables the identification of the parameters for analytical capture zone equations, is needed.
\end{abstract}

Key words: transmissivity, capture zone, aquifer test, Brazil.

\section{INTRODUCTION}

Transmissivity is an important hydraulic parameter to determine the amount of water that flows horizontally across a unit hydraulic gradient through a unit width of aquifer of given saturated thickness (Freeze and Cherry 1979). Transmissivity depends on the shape, amount, and interconnectivity of void spaces, or permeability structure. This parameter is often quantified via grain size analysis, permeameters, aquifer tests, slug tests, or groundwater numerical models, which estimate values from small- to regional-scales (Rovey and Cherkauer 1995, Cheong et al. 2008, Galvão et al. 2015a).

Correspondence to: Paulo Henrique Galvão

E-mail: hidropaulo@gmail.com 
The techniques used to estimate transmissivity may present certain limitations, such as time/spatial scale, viability, or even economically. For example, grain size analysis, slug tests, or the use of permeameters may have limitations in scale, where the calculated values only correspond to the local part of rock/aquifer analyzed (Millham and Howes 1995, Butler and Healy 1998, Cheong et al. 2008). Depending on the lithological composition of the aquifer, the values estimated from these techniques should not be extended to larger portion of the aquifer (Vienken and Dietrich 2011, Galvão et al. 2015a).

Regarding the aquifer tests, they generally need 24 hours minimum in porous media aquifers to produce reliable data, being considered a long test. In karst aquifers, which are hydraulically governed by the interaction between highly conductive conduit network and/or low-conductive rock matrix under variable boundary conditions (Liedl et al. 2003), they require longer duration tests of 48 hours, 72 hours, or even more, to produce good-quality results. Due to it, tests made in urban areas may cause disturbances to the local population, because the groundwater pumped is momentarily disconnected from the water supply networks, resulting in nonpublic supply and waste for a long time. Other limiters are the costs of fieldworks, related to workforce required for operation and maintenance of the facilities, as well as the consumption of energy from the pumps to extract the groundwater (Feitosa et al. 2008).

One technique also used to estimate transmissivity, but little adopted, is the capture zone analysis, defined as the area of an aquifer in which all the water will be removed by a pumping well or wells within a certain time period (Todd 1980, Grubb 1993). The capture zone method and the equation derivations have been developed and well utilized for the use with WHPA (Well Head Protection Area), a semi-analytical groundwater flow model used in the U.S. Environmental Protection Agency wellhead protection program (USEPA 1987, 1993, 1994). These equations, which will be shown and commented more ahead, require values of transmissivity or hydraulic conductivity, which using simple derivations, it is possible to estimate indirectly these parameters. In some cases, the equations can be superimposed to calculate the capture zone of multiple well systems (Javandel and Tsang 1986, Galvão et al. 2015a), as well as computer models can be used for analyzing multiple wells and heterogeneous aquifers (McElwee 1991, Bair and Roadcap 1992).

In this paper, capture zone analytical equations to estimate transmissivity values were used in a portion of the Sete Lagoas Karst Aquifer, located within the urban area of the municipality of Sete Lagoas, Brazil. The objective was to verify the effectiveness of the methodology as an alternative in situations where other traditional methods present implementation difficulties. From the potentiometric surface map, a significant capture zone was recognized, where analytical equations were utilized. The transmissivities calculated from this technique were compared with field data estimated by aquifer tests conducted in the same region. A sensitivity analysis was also performed to identify possible discrepancies between the analytical and field data results.

\section{SITE DESCRIPTION}

The aquifer studied was the Sete Lagoas Karst Aquifer (Pessoa 1996), located in the municipality of Sete Lagoas, Brazil, $70 \mathrm{~km}$ northwest of Belo Horizonte, the state capital (Figure 1). The city has a population greater than 230,000 over an area of $538 \mathrm{~km}^{2}$ (IBGE 2015). The greatest population density is located in the older urban areas of the city. The current water supply is almost entirely groundwater from the aquifer sourced from private and public wells. The public supply wells are managed by the Water Supply and Sewage Service (SAAE) [SAAE - Serviço Autônomo de Água e Esgoto]. The highest pumping rates (greater than $100 \mathrm{~m}^{3} / \mathrm{d}$ ) are located in areas with the greatest population density (Figure 1). 


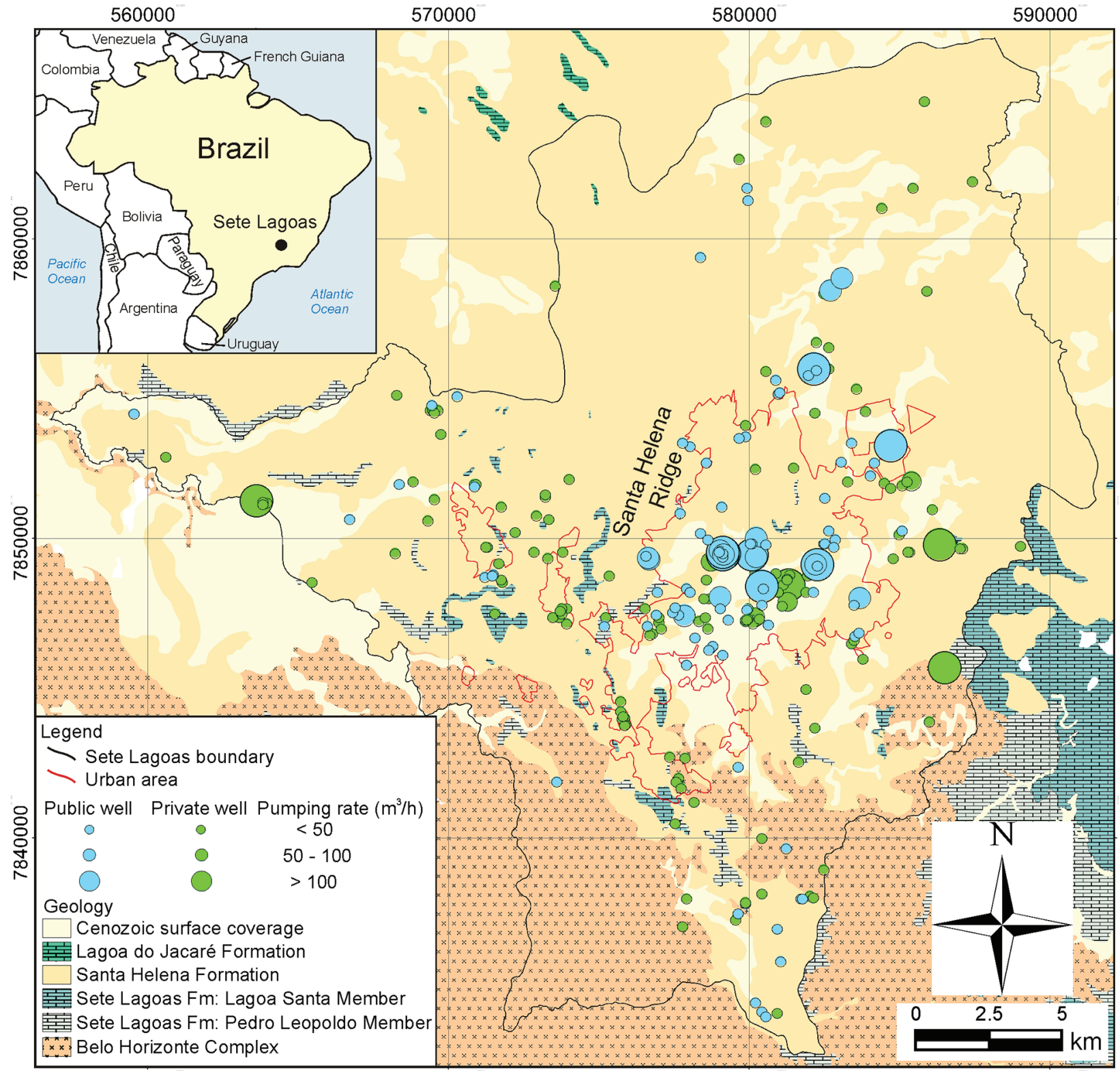

Figure 1 - Location map in UTM coordinates of Sete Lagoas showing the municipal boundary, the urban area, the well locations (private and public) and the geology of the study area.The highest pumping rates (greater than $100 \mathrm{~m}^{3} / \mathrm{d}$ ) are located in the areas with the greatest population density.

The region is located in the São Francisco Craton, where carbonate argillo-arenaceous sediments are emplaced giving origin to the Bambuí Group (Branco and Costa 1961, Oliveira 1967, Schöll and Fogaça 1973, Dardenne 1978, Schobbenhaus 1984, Ribeiro et al. 2003, Tuller et al. 2010, Galvão et al. 2016). Within the municipal boundary, the Bambuí Group is represented by the following Neoproterozoic formations, from the base to the top: Sete Lagoas (carbonate sequence); Serra de Santa Helena (siltstones, phyllites, slate, arkoses, and marlstones); and Lagoa do Jacaré (oolitic limestones). The area is in a context of basin border, where the basement is represented by gneissic rocks associated with granitoids and migmatite zones from the Belo Horizonte Complex (Tuller et al. 2010). 
The hydrostratigraphic relationships for the Sete Lagoas Karst Aquifer and spatial distribution are given in Pessoa (1996) and Galvão et al. (2015b). The aquifer, which is approximately 75 meters thick within the urban area of the city, consists of limestones from the Sete Lagoas Formation, composed of two members: the Pedro Leopoldo, at the base, composed of fine limestones, dolomites, marlstones and pelites; and the Lagoa Santa, on the top, composed of medium-grained black limestones. The primary porosity and matrix permeability can be considered low (Moore 1989) and the secondary porosity is mostly filled by the precipitation of calcite (Tonietto 2010). The majority of groundwater migrates through dissolution features characterized as tertiary porosity (Galvão et al. 2015b).

Results from geologic mapping and optical well logging suggest the urban area of Sete Lagoas (Figure 1) is primarily located in a graben, filled with limestones from the Sete Lagoas Formation, overlying Cenozoic unconsolidated sediments, and occasionally covered by competent rocks from the Serra de Santa Helena Formation. The bedding planes are the most relevant discontinuities for groundwater circulation, where two dominant solutionally enlarged bedding planes with high permeability and significant storage capacity were developed. These two karstic bedding planes become thinner to the northeast (Galvão et al. 2015b).

In the central urban area, where the study was conducted, the karst aquifer is confined, where the potentiometric surface is above the two karstic bedding planes. Some exceptions locally occur in the shallowest bedding plane, which sometimes it is found dry due to high localized well supply extractions, causing temporary unconfining conditions (Galvão et al. 2015b). A schematic hydrogeological section of the Sete Lagoas describes the groundwater circulation and aquifer geometry (Figure 2).

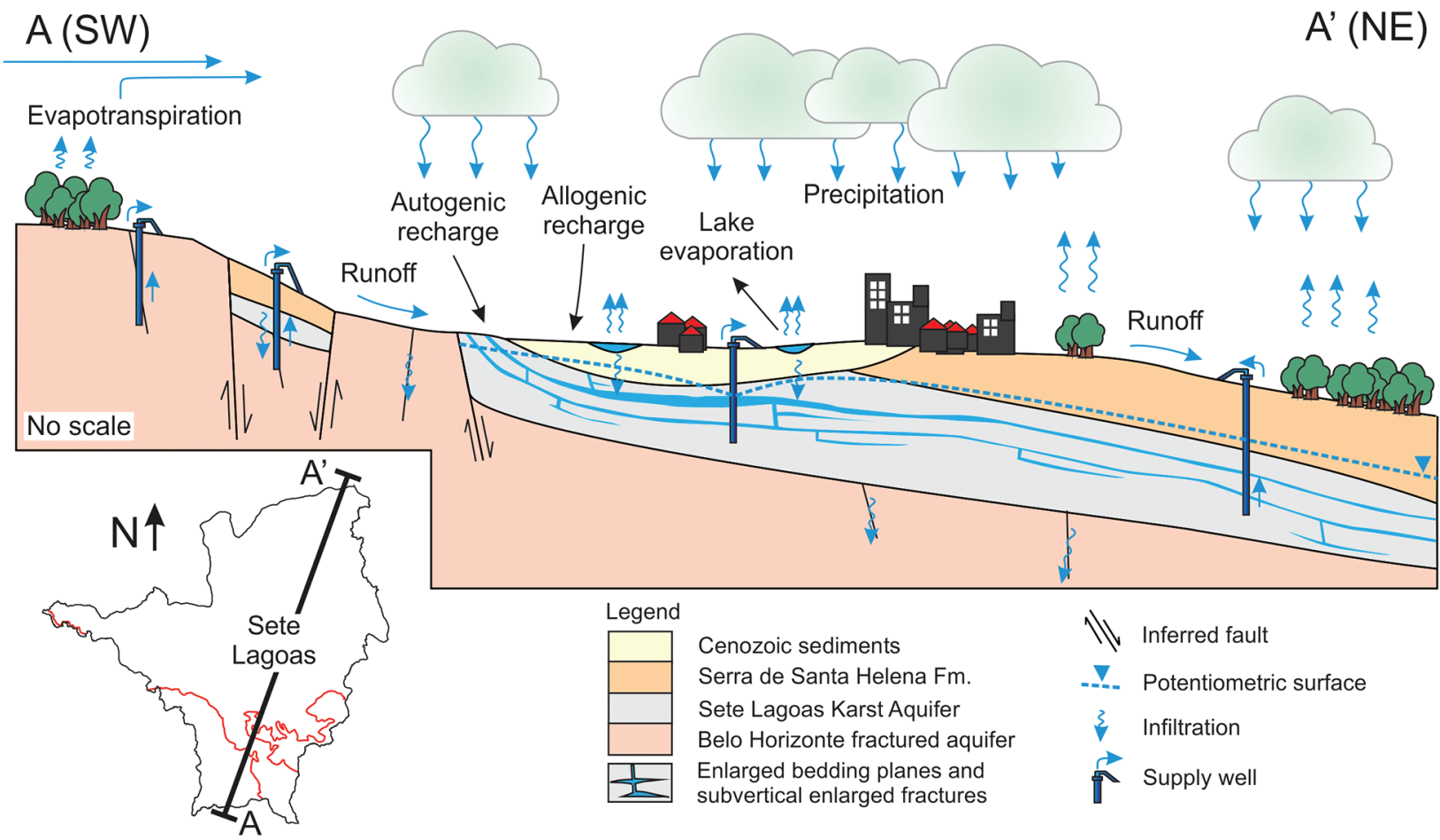

Figure 2 - A schematic hydrogeological section of the city of Sete Lagoas describing the groundwater circulation in the central urban area. The karst aquifer is confined, where the potentiometric surfaces are above the two karstic bedding planes. Locally, the shallowest bedding plane is found dry due to high well supply extractions, causing temporary unconfined conditions (modified from Galvão et al. in press). 


\section{MATERIALS AND METHODS}

\section{POTENTIOMETRIC SURFACE MAP AND CAPTURE ZONE ANALYSIS}

To develop a potentiometric surface map (Figure 3), measurements of the water table were taken only in the SAAE's supply wells extracting water from the Sete Lagoas Karst Aquifer. The well casing elevation data were acquired using a SRTM image (Shuttle Radar Topography Mission). The accuracy in the use of this data is less than $5 \mathrm{~m}$ (Demétrio et al. 2006).

The capture zone geometry was determined based on the flow lines from the potentiometric surface map. Based on this geometry, analytical equations (1) and (2), derived for confined aquifers by Todd (1980) and Grubb (1993) delineating the edges of a capture zone, according to the local hydrogeological configuration (Figure 2), were used:

$$
\begin{aligned}
& X_{L}=\frac{-Q_{r}}{2 \pi T i} \\
& Y_{L}=\frac{Q_{r}}{2 T i}
\end{aligned}
$$

With a simple derivation, isolating the parameter $T$ from the (1) and (2) equations, it is possible to estimate the transmissivity, $T\left[\mathrm{~L}^{2} / \mathrm{t}\right]$, in a multiple well system by the equations (3) and (4):

$$
\begin{aligned}
& T_{x}=\frac{-Q}{2 \pi X_{L} i} \\
& T_{y}=\frac{Q}{2 Y_{L} i}
\end{aligned}
$$

where $T_{x x}$ and $T_{y y}\left[\mathrm{~L}^{2} / \mathrm{t}\right]$ are the transmissivities in their respective directions, $Q\left[\mathrm{~L}^{3} / \mathrm{t}\right]$ is the total discharge rate, $X_{L}[\mathrm{~L}]$ is the distance from the pumping well to the downgradient edge of the capture zone (stagnation point), $Y_{L}[\mathrm{~L}]$ is the half width of the maximum capture zone, and $i$ [dimensionless] is the hydraulic gradient (Figure 3b).

The discharge rate was estimated by summing the pumping rate values from public supply wells (provided by SAAE and Servmar Environmental \& Engineering) and private wells (acquired from the online SIAGAS's database - http://siagasweb.cprm.gov.br) extracting groundwater within the capture zone. The total discharge rate value estimated was $75,000 \mathrm{~m}^{3} / \mathrm{d}$.

\section{SENSITIVITY ANALYSIS AND GIS DATABASE}

The next step was to estimate the $T$ based on the best fit-empirical capture zone in comparison to the potentiometric capture zone, using the equation (5) that describes the empirical edge of the capture zone for a confined aquifer (Todd 1980, Grubb 1993):

$$
x=\frac{-y}{\tan [2 \pi T i y / Q]}
$$

where $x[\mathrm{~L}]$ is the distance parallel to the hydraulic gradient and $y[\mathrm{~L}]$ is the distance perpendicular to the hydraulic gradient. 

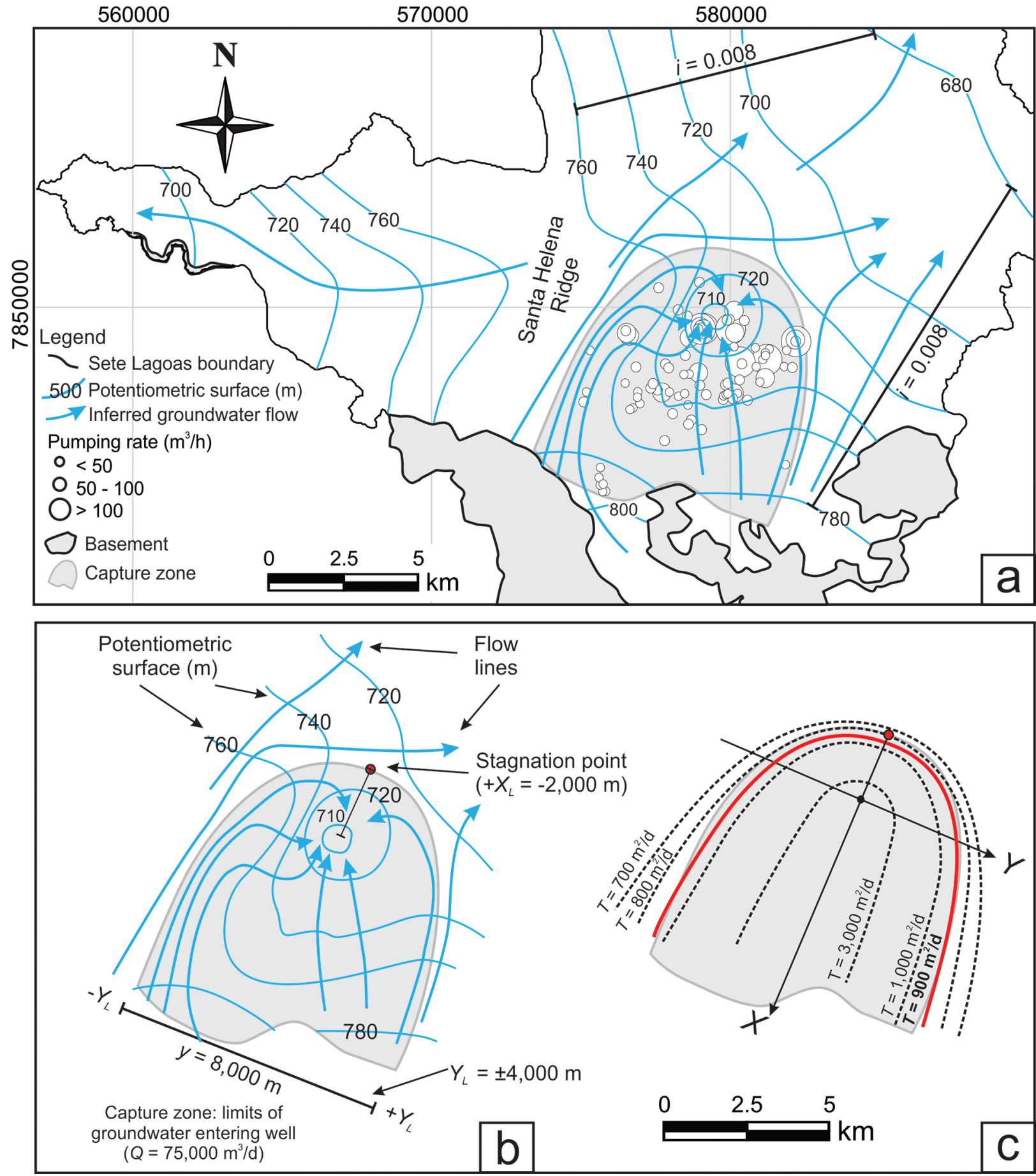

Figure 3 - Potentiometric surface map, where a capture zone is recognized (a). Description of the capture zone model shape, its parameters and respective variables (b). Comparison between the best-fit empirical capture zone curves (red solid and dashed black lines) and the potentiometric surface capture zone (grey area) assuming variations of transmissivities (c) (modified from Galvão et al. 2015a).

Thus, different $x$ and $y$ values can be calculated by adjusting only intervals of $T$ values from the equation (5), and then different empirical capture zones can be generated in a Cartesian coordinate system 
(e.g. using a spreadsheet program). These results can be used as a sensitivity analysis, evaluating the possible variability in the $T$ results found via capture zone method by potentiometric surface map and via aquifer tests performed in the same region (Figure 3c).

All the data sets, such as well locations, measurements of the water table for the potentiometric surface map (and the use of kriging interpolation method), and values of transmissivity by aquifer tests, were entered in a GIS database and georeferenced in the ArcGIS10.1 software. The coordinate system was Universal Transverse Mercator (UTM) projection, Zone 23, datum SAD 69, with units in meters.

\section{AQUIFER TEST}

For comparison, seven long duration (48 hours) transient pumping tests were conducted to measure the transmissivity using the Theis (1935) method (Table I and Figure 4). The tests consisted of pumping a well at a constant rate and monitoring the change in aquifer level in one (or more than one) observation well situated at a distance $r[\mathrm{~L}]$ of the pumped well. All the wells tested were the SAAE's supply wells located in the central urban area, extracting water from the Sete Lagoas Karst Aquifer.

Pumping tests performed in karst regions should always be taken with caution, due to their inherent heterogeneity and anisotropy. However, the tests conducted in this research generated plausible timedrawdown data ( $t$ versus $s$ ), consistent to the Theis (1935) type-curve solution.

\section{RESULTS}

\section{CAPTURE ZONE ANALYSIS BY POTENTIOMETRIC SURFACE MAP}

According to the potentiometric surface map and the groundwater flow lines information, the Santa Helena Ridge behaves as a watershed boundary. The eastern portion of the map has groundwater flowing to the northeast, while the western portion has groundwater flowing to the northwest. In the central portion of the map, there is a flow convergence, generated by a considerable capture zone of $68 \mathrm{~km}^{2}$, approximated, explained by the high pumping rate from a multiple well system (Figure 3a).

Utilizing equations (1) and (2), with a stagnation point $\left(X_{L}\right)=-2,000 \mathrm{~m}$; half width of capture zone $\left(Y_{L}\right)$ $= \pm 4,000 \mathrm{~m}$; total discharge rate $(Q)=75,000 \mathrm{~m}^{3} / \mathrm{d}$; and hydraulic gradient $(i)=0.008$ (Figures $3 \mathrm{a}, \mathrm{b}$ ), the analytical transmissivities were estimated:

$$
\begin{gathered}
T_{x}=\frac{-75,000}{2 * 3.1416 *(-2,000) * 0.008} \cong 750 \mathrm{~m}^{2} / \mathrm{d}\left(0.9 \times 10^{-2} \mathrm{~m}^{2} / \mathrm{s}\right) \\
T_{y}= \pm \frac{75,000}{2 * 4,000 * 0.008} \cong 1,170 \mathrm{~m}^{2} / \mathrm{d}\left(1.3 \times 10^{-2} \mathrm{~m}^{2} / \mathrm{s}\right)
\end{gathered}
$$

Thus, the transmissivities, via analytical method, range between 750 and $1,170 \mathrm{~m}^{2} / \mathrm{d}$. As the thickness of the aquifer in this portion is about $75 \mathrm{~m}$ (Galvão et al. 2015b), the estimated hydraulic conductivity, $K$ [L/t], ranging from 10 to $16 \mathrm{~m} / \mathrm{d}\left(1.2 \times 10^{-4}-1.8 \times 10^{-4} \mathrm{~m} / \mathrm{s}\right)$.

\section{AQUIFER TESTS}

The seven aquifer tests (Table I) indicated $T$ values between $330 \mathrm{~m}^{2} / \mathrm{d}$ (northeast region) and 3,360 $\mathrm{m}^{2} / \mathrm{d}$ (next to the Santa Helena Ridge foothills). The wells tested in the central urban area also showed high values of transmissivity, around $1,500 \mathrm{~m}^{2} / \mathrm{d}$. In the north, the $T$ values were about $600 \mathrm{~m}^{2} / \mathrm{d}$ (Figure 4). 
TABLE I

Information about seven long duration (48 h) transient pumping tests conducted in the SAAE's supply wells. All the tests were pumping water from the Sete Lagoas Karst Aquifer.

\begin{tabular}{|c|c|c|c|c|c|c|}
\hline $\begin{array}{l}\text { Pumping } \\
\text { well }\end{array}$ & $\begin{array}{l}\text { Discharge } \\
\left(\mathrm{m}^{3} / \mathrm{h}\right)\end{array}$ & $\begin{array}{l}\text { Pumping well static } \\
\text { water level (m) }\end{array}$ & $\begin{array}{l}\text { Observation } \\
\text { well }\end{array}$ & $\begin{array}{c}\text { Distance from } \\
\text { pumping well (m) }\end{array}$ & $\begin{array}{c}\text { Observation well } \\
\text { static water level (m) }\end{array}$ & $\begin{array}{l}\text { Transmissivity }\left(\mathrm{m}^{2} / \mathrm{d}\right) \\
\text { from observation well }\end{array}$ \\
\hline PT-12 & 96.2 & 57.39 & PT-11 & 70.1 & 57.02 & 1,500 \\
\hline PT-15 & 40.4 & 49.67 & PT-14 & 200.7 & 55.48 & 1,400 \\
\hline PT-19 & 128.2 & 9.91 & PT-21 & 72.4 & 9.74 & 980 \\
\hline PT-22 & 92.2 & 12.08 & PT-25B & 75.1 & 9.36 & 330 \\
\hline \multirow{2}{*}{ PT-40 } & \multirow{2}{*}{61.5} & \multirow{2}{*}{0.76} & PT-39 & 175.2 & 2.14 & 940 \\
\hline & & & PT-41 & 230.3 & 2.52 & 980 \\
\hline \multirow{2}{*}{ PT-64 } & \multirow{2}{*}{194.1} & \multirow{2}{*}{22.45} & PT-63 & 310.0 & 29.11 & 580 \\
\hline & & & PT-66 & 70.0 & 18.75 & 650 \\
\hline PT-105 & 47.1 & 29.72 & PT-29 & 28.3 & 31.66 & 3,360 \\
\hline
\end{tabular}

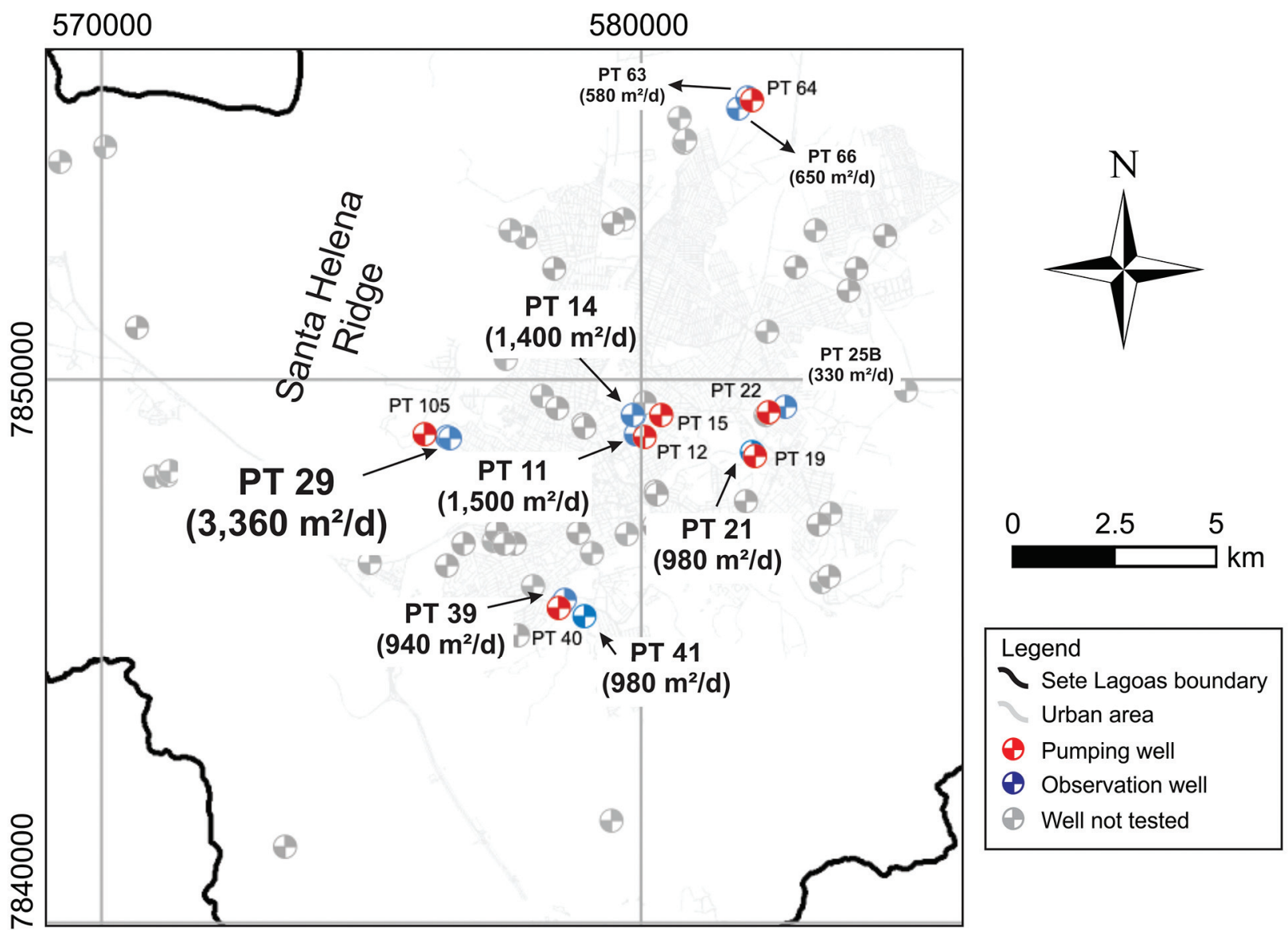

Figure 4 - Transmissivity values, $T$, estimated by long duration (48 h) transient pumping tests. The highest $T$ values were noted in the central urban area of Sete Lagoas and near the Santa Helena Ridge.

Making an average of all values, the average $T$ would be about $1,190 \mathrm{~m}^{2} / \mathrm{d}$. Discarding the value of $T$ near the Santa Helena Ridge, which is showing to be atypical in comparison to the others, the average $T$ of the region would be around $920 \mathrm{~m}^{2} / \mathrm{d}$. 


\section{SENSITIVITY ANALYSIS}

To evaluate a possible variability using the capture zone analytical method, a sensitivity analysis was conducted adjusting $T$ values estimated from aquifer tests within the capture zone, found in the Figure 3 ( $\left(T=700 ; 800 ; 900 ; 1,000 ; 3,000 \mathrm{~m}^{2} / \mathrm{d}\right.$ ) to assess the relative accuracy (Figure $3 \mathrm{c}$ ). Empirical curves were generated simulating capture zone edges for each interval. The best-fit empirical capture zone was found with a transmissivity $=900 \mathrm{~m}^{2} / \mathrm{d}\left(1.1 \times 10^{-2} \mathrm{~m}^{2} / \mathrm{s}\right.$ - see solid black and dashed lines on Figure $\left.3 \mathrm{c}\right)$, resulting in a hydraulic conductivity value of $12 \mathrm{~m} / \mathrm{d}\left(1.4 \times 10^{-4} \mathrm{~m} / \mathrm{s}\right)$. The calculation of the best-fit empirical capture zone $\left(T=900 \mathrm{~m}^{2} / \mathrm{d}\right)$ can be seen below:

Part A: half width of the capture zone, $X_{L}[\mathrm{~L}]$ :

$$
Y_{L}= \pm \frac{75,000}{2 * 900 * 0.008} \pm 5,210 m
$$

Part B: distance to the stagnation point, $X_{L}[\mathrm{~L}]$ :

$$
X_{L}=\frac{-75,000}{2 * 3.1416 * 900 * 0.008} \cong-1,660 \mathrm{~m}
$$

Part C: shape of the curve describing the capture zone, $x[\mathrm{~L}]$. The following values are for one-half of the capture zone, which is symmetrical about the $x$-axis:

$$
x=\frac{-y}{\tan [(2 * 3.1416 * 900 * 0.008 y) / 75,000]}=\frac{-y}{\tan (0.000603 y)}
$$

The value of $T=900 \mathrm{~m}^{2} / \mathrm{d}$ from the best-fit empirical method is in the same order of magnitude compared to the estimated values via analytical method $\left(750-1,170 \mathrm{~m}^{2} / \mathrm{d}\right)$. The ranges also present the same order of magnitude of average $T$ from pumping tests $\left(1,190\right.$ and $\left.920 \mathrm{~m}^{2} / \mathrm{d}\right)$.

\section{DISCUSSION}

The potentiometric surface map allowed, via groundwater flow lines, the recognition of a capture zone of 68 $\mathrm{km}^{2}$ in the central portion of the municipality (Figure 3a). This significant zone is a result of high pumping rate made by multiple wells (more than 70 wells) located in that region. From the shape of the capture zone (allowing the identification of parameters as stagnation point and width of the maximum capture zone, Figure 3b), it was possible to use the equations derived by Todd (1980) and Grubb (1993). Without these characteristics, the capture zone method would not be applied. According to the analysis and calculations, transmissivity values were estimated between 750 and $1,170 \mathrm{~m}^{2} / \mathrm{d}\left(0.9 \times 10^{-2}-1.3 \times 10^{-2} \mathrm{~m}^{2} / \mathrm{s}\right)$, and hence hydraulic conductivity ranging from 10 to $16 \mathrm{~m} / \mathrm{d}\left(1.2 \times 10^{-4}-1.8 \times 10^{-4} \mathrm{~m} / \mathrm{s}\right)$.

The transmissivities estimated by aquifer tests showed values between $330 \mathrm{~m}^{2} / \mathrm{d}$ (northeast region), $3,360 \mathrm{~m}^{2} / \mathrm{d}$ (near the Santa Helena Ridge), 1,500 $\mathrm{m}^{2} / \mathrm{d}$ (central area), and around $600 \mathrm{~m}^{2} / \mathrm{d}$ (north) (Figure 4). The differences of values are explained by distinct thicknesses in the solutionally enlarged bedding planes in the Sete Lagoas Karst Aquifer. In zones where the karstification was more intense, it is common high values of $T$ and $K$. These high values were confirmed in the central urban area of Sete Lagoas and close to the Santa Helena Ridge foothills, where 30 optical well loggings in SAAE's supply wells were made and confirmed the karstified zones (Galvão et al. 2015b). The region is located where the Cenozoic 
unconsolidated sediments are above the Sete Lagoas Formation's limestones. This geological setting results in an allogenic infiltration (when non-karst areas recharge the karst aquifer) by acid water derived from respiration or oxidation of organic matter (Galvão et al. in press).

To the north, where $T$ and $K$ values are lower, the Sete Lagoas Formation is deeper, being covered by competent and impermeable rocks from the Serra de Santa Helena Formation. This configuration results in less intense karstified zones, due to less acid water infiltration rate that could unbalance the system hydrochemically.

The average $T$, by aquifer tests within the capture zone, is $1,190 \mathrm{~m}^{2} / \mathrm{d}$ (or $920 \mathrm{~m}^{2} / \mathrm{d}$, discarding the highest $T$ values near the Santa Helena Ridge). Comparing the average $T$ with values estimated via analytical capture zone method $\left(750-1,170 \mathrm{~m}^{2} / \mathrm{d}\right)$, similarities between them is noticed, in the same order of magnitude.

Despite the similarities, such comparison should always be taken with caution, being considered even a coincidence. To reduce doubts and confirm the relevance of the analytical capture zone method, a sensitivity analysis via empirical curves was made using the transmissivity ranges measured by aquifer tests (Figure 3c). Exactly the empirical capture zone found with a transmissivity $=900 \mathrm{~m}^{2} / \mathrm{d}$ has the best fit with the capture zone shape observed in the potentiometric surface map (see solid black lines on Figure $3 c)$. This analysis corroborates the effectiveness of the analytical method, and hence the reliability of the calculated results.

\section{CONCLUSIONS}

The equations derived for capture zone method analysis proved to be a viable and economical tool for transmissivity estimates, and hence for hydraulic conductivity calculations. Therefore, the method can replace possibly the need for aquifer tests in cases where these tests are not feasible.

However, the minimum requirements to use the capture zone analysis, a priori, are: a reliable potentiometric surface map where a capture zone with geometry can be recognized, which enables the identification of the parameters needed for the analytical equations.

The research was developed in a heterogeneous and anisotropic karst aquifer. This could result in discrepancies in transmissivity values. However, the analytical values compared to the aquifer tests showed similarities, being confirmed by a sensitivity analysis.

The overall transmissivity value for the portion studied of the Sete Lagoas Karst Aquifer can be considered around $900 \mathrm{~m}^{2} / \mathrm{d}\left(10^{-2} \mathrm{~m}^{2} / \mathrm{s}\right)$, while the hydraulic conductivity is approximately $12 \mathrm{~m} / \mathrm{d}(1.4 \mathrm{x}$ $\left.10^{-4} \mathrm{~m} / \mathrm{s}\right)$.

\section{ACKNOWLEDGMENTS}

The research was funded by Servmar Environmental \& Engineering and by Fundação de Amparo à Pesquisa do Estado de São Paulo (FAPESP, process 2012/12846-9). Special thanks go to Serviço Autônomo de Água e Esgoto (SAAE).

\section{REFERENCES}

BAIR ES AND ROADCAP GS. 1992. Comparison of flow models used to delineate capture zones of wells: 1 . Leaky-confined fractured-carbonate aquifer. Ground Water 30(2): 199-211. 
BRANCO JR AND COSTA MT. 1961. Belo Horizonte-Brasilia roadmap tour. In: Brazilian Congress of Geology, Brasilia. Radioactive Research Institute, Federal University of Minas Gerais (UFMG), Publication 15, Belo Horizonte, p. 25.

BUTLER JJ AND HEALY JM. 1998. Relationship between pumping-test and slug-test parameters: Scale effect or artifact? Ground Water 36(2): 305-313.

CHEONG JY, HAMM SY, KIM HS, KO EJ, YANG K AND LEE JH. 2008. Estimating hydraulic conductivity using grain-size analyses, aquifer tests, and numerical modeling in a riverside alluvial system in South Korea. Hydrogeol J 16: $1129-1143$.

DARDENNE MA. 1978. Synthesis on the stratigraphy of Bambuí Group in Central Brazil. In: Brazilian Congress of Geology, 30, Recife. Annals Recife: Braz Soc of Geol 1978(2): 597-610.

DEMÉTRIO JGA, CORREIA LC AND SARAIVA AL. 2006. Using SRTM images to developing potentiometric maps. In: Brazilian Groundwater Congress. Abstracts. Curitiba, ABAS, 176 p.

FEITOSA FAC, MANOEL FILHO J, FEITOSA EC AND DEMETRIO JGA. 2008. Hidrogeologia: conceitos e aplicações [Hydrogeology: concepts and aplications]. $3^{\mathrm{a}}$ ed., Rio de Janeiro: CPRM/LABHID, 812 p.

FREEZE AR AND CHERRY JA. 1979. Groundwater: Englewood Cliffs, New Jersey, Prentice-Hall, 604 p.

GALVÃO P, HALIHAN T AND HIRATA R. 2015a. The Karst Permeability Scale Effect of Sete Lagoas, MG, Brazil. J Hydrol 531: 85-105.

GALVÃO P, HALIHAN T AND HIRATA R. 2015b. Evaluating karst geotechnical risk in the urbanized area of Sete Lagoas, Minas Gerais, Brazil. Hydrogeol J 23(7): 1499-1513.

GALVÃO P, HIRATA R, CORDEIRO A, OSÓRIO DB AND PEÑARANDA J. 2016. Geologic conceptual model of the municipality of Sete Lagoas (MG, Brazil) and the surroundings. An Acad Bras Cienc 88: 35-53.

GRUBB S. 1993. Analytical model for estimation of steady-state capture zones of pumping wells in confined and unconfined aquifers. Ground Water 31(1): 27-32.

IBGE - Brazilian Institute of Geography and Statistics. 2015. Basic Municipal Information. Available: http://www.ibge.gov.br/ cidadesat/topwindow.htm?1 Accessed on October 2015.

JAVANDEL IC AND TSANG CF. 1986. Capture zone types curves: A tool for aquifer cleanup. Ground Water 24(5): 616-625.

LIEDL R, SAUTER M, HÜCKINGHAUS D, CLEMENS T AND TEUTSCH G. 2003. Simulation of the development of karst aquifers using a coupled continuum pipe flow model. Water Resour Res 39(3): 1057.

MCELWEE CD. 1991. Computer notes: Capture zones for simple aquifers. Ground Water 29(4): 587-590.

MILLHAM NP AND HOWES BL. 1995. A comparison of methods to determine K in a shallow coastal aquifer. Ground Water 33(1): 49-57.

MOORE CH. 1989. Carbonate diagenesis and porosity. Development in sedimentology 46. Amsterdam: Elsevier, 338 p.

OLIVEIRA MAM. 1967. Contribution to the geology of the southern part of the São Francisco Basin and adjacent areas. In: Collection of Reports Exploration, Rio de Janeiro 1. Petrobras (3): 71-105.

PESSOA P. 1996. Hydrogeological characterization of the region of Sete Lagoas - MG: Potentials and Risks. Master Thesis. Department of Geosciences, University of São Paulo. São Paulo. (Unpublished).

RIBEIRO JH, TULLER MP AND DANDERFER FILHO A. 2003. Geological mapping of the region of Sete Lagoas, Pedro Leopoldo, Matozinhos, Lagoa Santa, Vespasiano, Capim Branco, Prudente de Morais, Confins and Funilândia, Minas Gerais State, Brazil (scale 1:50,000). $2^{\text {nd }}$ ed., Belo Horizonte, 54 p.

ROVEY II CW AND CHERKAUER DS. 1995. Scale dependency of hydraulic conductivity measurements. Ground Water 33(5): 769-780.

SCHOBBENHAUS C. 1984. Geology of Brazil. National Department of Mineral Production, p. 275-277.

SCHÖLL WU AND FOGAÇA ACC. 1973. Stratigraphy of the Espinhaço in the Diamantina region. In: Symposium on Geology of Minas Gerais State, Brazil, 1. Acts. Belo Horizonte: Braz Geol Soc, p. 55-73.

THEIS CV. 1935. The relation between the lowering of the piezometric surface and the rate and duration of discharge of a well using groundwater storage. Trans Am Geophys Union 16: 519-524.

TODD DK. 1980. Groundwater Hydrology. J Wiley and Sons, NY, 535 p.

TONIETTO SN. 2010. Diagenesis and hydrothermal rocks in Proterozoic carbonates: Bambuí and Vazante Groups, São Francisco Basin. Master Thesis. Institute of Geosciences, University of Brasília. Federal District. (Unpublished).

TULLER MP, RIBEIRO JH, SIGNORELLI N, FÉBOLI WL AND PINHO JMM. 2010. Sete Lagoas - Abaeté Project, Minas Gerais State, Brazil. 6 geological maps, scale 1:100,000 (Geology Program of Brazil), 160 p.

USEPA - U.S. Environmental Protection Agency. 1987. Guidelines for Delineation of Wellhead Protection Areas. EPA/440/687/010 report.

USEPA - U.S. Environmental Protection Agency. 1993. Wellhead Protection: A Guide for Small Communities. EPA/625/R-93/002 report, $144 \mathrm{p}$. 
USEPA - U.S. Environmental Protection Agency. 1994. Ground Water and Wellhead Protection Handbook. EPA/625/R-94/001 report, $269 \mathrm{p}$.

VIENKEN T AND DIETRICH P. 2011. Field evaluation of methods for determining hydraulic conductivity from grain size data. J Hydrol 400: 58-71. 